\title{
Mothers' Complex Talk when Sharing Books with their Toddlers: Book Genre Matters
}

\section{Angela Nyhout and Daniela K O'Neill}

University of Waterloo, Canada

\begin{abstract}
This study investigated the influence of book genre (narrative or didactic) on mothers' language use during a book sharing interaction with their 18- to 25-month-olds. Motherchild dyads were videotaped sharing both a narrative and a didactic book, adapted from two commercially-available books, and matched in terms of length, quantity of text, and target content. A greater proportion of mothers' talk was complex (i.e., predictions, text-to-life comparisons) during narrative book sharing than during didactic book sharing. Mothers also used a greater variety of verb tenses and referenced more mental states during narrative book sharing. These results differ from findings from previous studies with older children where it has been concluded that didactic books offer greater opportunities for complex talk than narrative books. The results also highlight the importance of taking situational factors into account when investigating parent-child communicative interactions.
\end{abstract}

\section{Keywords}

Parental input, complex talk, book sharing, narratives, situational factors

\section{Corresponding authors:}

Angela Nyhout and Daniela K. O'Neill, Department of Psychology, University of Waterloo, 200

University Avenue West, Waterloo, Ontario, N2L 3G I

Email: aknyhout@uwaterloo.ca or doneill@uwaterloo.ca 


\section{Mothers' Complex Talk when Sharing Books with their Toddlers: Book Genre Matters}

Different books can offer very different things to readers. However, studies investigating mother-child book sharing often overlook the important role the book itself may play in the interaction and conclude that mothers have a predominant communicative style with their children (e.g., Haden, Reese, \& Fivush, 1996; Heath, 1982; Pellegrini, Brody, \& Sigel, 1985; van Kleeck, Gillam, Hamilton, \& McGrath, 1997). Although there is no doubt that individuals show many consistencies in their communicative style, situational factors should not be ignored, as demonstrated in a long history of studies in social psychology (e.g,, Cansler \& Stiles, 1981; Ross, Amabile, \& Steinmetz, 1977) and sociolinguistics (e.g. Dewaele, Eckert, \& Rickford, 2001). Within the field of developmental psychology, situational factors such as context (e.g., play versus book reading; Beals \& Tabors, 1995; Lewis \& Gregory, 1987), stimulus type (e.g., printed versus electronic books; Korat \& Or, 2010), and certain book characteristics (e.g., Hoicka, Jutsum, \& Gattis, 2008; Reese, Cox, Harte, \& McAnally, 2003) have been shown to influence mothers' talk.

In 2003, van Kleeck highlighted the need for research investigating book features such as complexity, familiarity, and, genre. In this study, we asked whether the complexity of mothers' talk with their young children is influenced by one of these situational factors: the genre of picture book they are sharing.

\section{Measuring complex talk}

Mothers' talk is often measured in terms of its complexity, with talk that is decontextualized, or abstract, considered more complex and cognitively-demanding than more contextualized talk. Complex maternal talk has been demonstrated to positively influence children's general language abilities (Whitehurst, Falco, Lonigan, Fischel, DeBaryshe, \& Valdez-Menchaca, 1988), emergent literacy (Zevenbergen \& Whitehurst, 2003), narrative abilities (e.g., Harkins, Koch, \& Michel, 1994) and children's own abstract language use (Morgan \& Goldstein, 2004; van Kleeck et al., 1997). Moreover, mothers' and children's talk has been found to be more complex during book sharing than in other settings such as play and mealtimes (Hoff, 2010; Lewis \& Gregory, 1987; Sorsby \& Martlew, 1991).

The complexity of mothers' talk has been variously measured using such categories as abstraction (Price, van Kleeck, \& Huberty, 2009; Sorsby \& Martlew, 1991; van Kleeck et al., 1997), narrative vs. paradigmatic talk (Beals \& Snow, 1994; Lange \& Carroll, 2003), immediate vs. nonimmediate talk (Dickinson, De Temple, Hirschler, \& Smith, 1992), and 
describer- vs. comprehender-styles (Haden et al., 1996; Reese \& Cox, 1999). Studies that code utterances for level of abstraction typically employ four different levels, with the lowest level including utterances such as labels and the highest including utterances such as predictions and explanations. In studies comparing narrative to paradigmatic talk, narrative talk involves event descriptions, discussions of cause-and-effect, mental states, and relevant experiences in the child's own life (Lange \& Carroll, 2003). In contrast, paradigmatic talk is static and focused on labelling objects and their perceptual features. The immediate and nonimmediate talk distinction (Dickinson et al., 1992) places labels and feature descriptions under immediate talk, and the reflection upon and analysis of events and the drawing of connections between the book and the child's life under nonimmediate talk. Finally, a describer-style focuses on description, whereas a comprehender-style focuses on story meaning (Haden et al., 1996; Reese \& Cox, 1999).

In using these indices of complexity, various types of abstract talk are commonly grouped under a single category. In addition to seven general types of abstract/complex talk that we examined in our study (see Method), we also focused on two further measures of abstract talk not consistently represented under the indices discussed above, but which may be particularly prevalent and important in talk with toddlers and young preschoolers: (1) mental state talk and (2) the use of non-present tenses. These types of talk encourage the child to consider alternate temporal and mental perspectives, respectively.

An extensive body of research shows that in everyday conversations and book sharing interactions, mothers' use of mental state terms with toddlers and preschoolers is both concurrently related to and predictive of children's use and comprehension of mental state terms (e.g., Moore, Furrow, Chiasson, \& Patriquin, 1994) and theory of mind abilities (e.g., Adrian, Clemente, \& Villaneuva, 2007).

The use of non-present tenses (i.e., past and future) necessarily decontextualizes talk and encourages children to take on different perspectives of situations. The majority of studies of tense use have focused on children's, rather than parents', production (e.g., O'Neill \& Atance, 2000; Pawlak, Oehlrich, \& Weist, 2006; Trudeau \& Sutton, 2011). In a study of complex tense use, it was found that children's use of modals to express past (e.g., "maybe the bell used to ring") and future uncertainty (e.g., we might see him again") increased steadily between the ages of two and five (O'Neill \& Atance, 2000). Although book sharing may be a rich context for encouraging the use of varied tenses and mental state talk, book genre may also influence these forms of abstract talk. 


\section{The influence of genre}

Interestingly, studies that have compared parent-child interactions during the sharing of different book genres have generally found more complex talk surrounding non-narrative book sharing than narrative book sharing. Torr and Clugston (1999) found that mothers talked more, asked more cognitively demanding questions, employed more reasoning, and used more technical terminology when reading non-narrative books with four-year-olds. Similarly, Anderson, Anderson, Lynch, and Shapiro (2004) found nearly double the number of utterances and more associations, clarifications, confirmations, and elaborations during non-narrative book reading as during narrative book reading between parents and their fouryear-olds. Although the authors did not display proportion data, the provided data suggest that these differences may have disappeared had they controlled for the quantity of talk. Using a four-level coding of abstraction, Price et al. (2009) found that mothers produced more utterances at the first (e.g., labelling), third (e.g., identifying similarities and differences), and fourth (e.g., providing explanations) levels when reading non-narrative books with their preschoolers. Mothers deviated from the text less during narrative book reading, which meant that fewer extra-textual utterances were observed at all levels.

Three methodological features of these previous studies, however, may have led to these findings of greater quantities of talk and more complex talk with non-narrative, as opposed to narrative, books: (1) the age of the children, (2) the complexity of the books, and (3) the experimental design.

Age of children. In the previous studies, children were preschool-aged. However, by the time children are three or four, parents tend to adhere to the text and contribute relatively little extra-textual talk (Kang, Kim, \& Pan, 2009; Moerk, 1985). Parents deviate from the text most, and thus contribute the most extra-textual talk, when reading to toddlers. Thus, if one were to investigate book sharing with younger children, one might find a different pattern of results. In our present study, indeed, we were interested in studying early book sharing interactions between mothers and their 18- to 25-month-olds, given that they lay the foundation for family book sharing interactions.

Complexity of books. The non-narrative books used in previous studies were similar to early encyclopedias, presenting, for example, information on an animal's appearance, diet, habitat, and behaviour, more suitable to the abilities of older preschool children. In contrast, nonnarrative books of the sort commercially aimed at babies and toddlers are often simple flashcard-like books that present isolated images of animals or objects on pages that are 
connected by some theme (e.g., farm animals), but not through any type of storyline. They may offer significantly less to talk about than the encyclopedic non-narrative books for preschoolers or narrative books for babies and toddlers.

Narrative books for younger versus older children can differ greatly with respect to the amount of detail contained in the text versus in pictures and illustrations. Storybooks designed for preschoolers, similar to those used in previous studies, generally tell the whole story in the accompanying text. In contrast, it is common for books for toddlers to contain little to no text. For example, Hug (Alborough, 2001) contains only the word "hug", with the events of the story relayed fully via the illustrations. Thus a parent must create the whole story. In previous studies, mothers may have contributed less extra-textual talk during narrative book reading because the entire story was presented in the text and such talk would have disrupted the story's flow. During non-narrative book sharing, extra-textual comments may have been less disruptive and therefore more common.

Experimental design. Previous studies did not always control for text, number of pages, and content. Neither Torr and Clugston (1999) nor Anderson et al. (2004) controlled for the amount of text or length of the narrative and non-narrative books. Indeed, Anderson et al. (2004) noted that given that their narratives contained approximately 1100 words, compared to 700 words in non-narrative books, it was surprising that there was more extra-textual talk in the non-narrative book. However, Sénéchal, Cornell, and Broda (1995) found that less is more when it comes to text. With text-heavy books, parents tended to adhere to the text and do relatively little extra-textual discourse. When no text was present, parents and children talked more. Price et al. (2009) did select books that were matched in terms of length and vocabulary diversity, but books in their narrative and non-narrative conditions focused on entirely different topics. To discern the influence of genre more clearly, books should be matched for text and length, and use the same target content. To our knowledge, no previous study has controlled for all of these variables.

\section{The present study}

Consider a parent in a book store looking for a new book for her toddler. If her intention is to buy a book that will teach her child new words and concepts, she may opt for a nonnarrative book that claims to be able to help teach her child new words, the ABCs, or how to count. Such claims may be explicit (e.g., "will increase your child's vocabulary") or implicit via brand names containing words synonymous with intelligence. In contrast, narrative books aimed at toddlers are usually not accompanied by any such claims. In this study, we 
investigated whether differences in book genre would result in differences in the complexity of maternal talk. Our focus was not on whether these two types of books can help teach children new words or concepts. Rather, our aim was to investigate the complexity of maternal talk as a means of demonstrating the relative benefits of narrative and nonnarrative books.

We controlled for the quantity of text, the number of pages, and target content (six animals) by adapting two commercially-available picture books to create a narrative and non-narrative version and mimic two types of books commonly read to toddlers: (1) simple, illustrated narratives and (2) ABC-like, or word learning books (referred hereto as didactic books). Thus, we manipulated whether the content was presented in a meaningful narrative context, or devoid of context, as in a typical didactic book. Given that the animals in the narrative version of each book were presented in a scene with environmental features (e.g., trees, cages) and background characters, one could logically expect mothers to simply talk more during narrative book sharing. For this reason, we examined the proportion of total maternal talk that was complex. We predicted that the narrative book would engender more complex talk (e.g., mental state talk, varied tenses, predictions) than the didactic book, for which more present-oriented talk was predicted (e.g., labels, feature descriptions).

\section{Method}

\section{Participants}

Participants were 25 mother-toddler dyads (mean child age $=21.3$ months, range $=18.9$ to 25.4 months, 12 girls). An additional two dyads participated but were dropped because they did not complete one book $(n=1)$ or the child refused to pay attention to the book $(n=1)$. Participants were recruited from a university laboratory database of local families recruited through advertisements in the community. All dyads spoke English as their primary language at home. Fifteen mothers (63\%) had completed a university degree, eight had completed a college diploma (33\%), and two had completed a high school diploma (8\%). Mothers ranged in age from 25 to 39 (mean $=32.6$ years).

On a questionnaire about home book sharing practices, mothers reported sharing books daily or multiple times a day with their child ( $84 \%$ of mothers), three to four times per week (12\%), and a few times a month (4\%). Mothers also reported that they first began sharing books with their child at an average age of 3.7 months (range $=0$ to 15 months). These maternal report data suggest that book sharing was a regular and familiar activity for all but one of the dyads who took part. 


\section{Materials and Design}

Two picture-books, Good Night, Gorilla (Rathmann, 1994) and Don't Wake Up the Bear! (Murray, 2003) were adapted to create our stimuli. Good Night, Gorilla tells the story of a zoo keeper making his rounds through the zoo at dusk to make sure all the animals are locked away for the night. Little does the zoo keeper know, the gorilla (the first animal to whom he says goodnight) has stolen his keys and follows him through the zoo and releases five other animals (elephant, lion, giraffe, hyena, and armadillo) after the zoo keeper has checked on them. The animals then follow the zoo keeper back to his house. We ended the story at this point. Don't Wake Up the Bear! tells the story of woodland animals trying to find a warm place to sleep on a cold winter's eve. We first see a bear sleeping in his cave. Five animals (hare, badger, fox, squirrel, and mouse) come by, one-by-one, and decide to cuddle up to the bear to keep warm (see Table 1). The original story continues, but to ensure the two versions of our books (narrative and didactic) were equal in length, we ended the story at this point with all five animals sleeping with the bear.

These two books were chosen because of their similarity on a number of dimensions: both include six animals; both begin with a single animal and each subsequent page includes a new animal joining the preceding animal(s); and both have an ignorant character who does not know about the main events taking place (i.e., zoo keeper and sleeping bear).

Each original book yielded two books for our study: one narrative and one didactic (renamed Animals at the Zoo for Good Night, Gorilla and Animals in the Woods for Don't Wake Up the Bear!). The narrative and didactic version of each book was equated for length, amount of text (names of the six animals), and the specific target content (i.e., the six animals). (See Table 1 for a description of the two versions of Animals in the Woods.)

The manipulation of interest was whether the six animals were presented in keeping with the original illustrated story context of the commercial version or cropped from the original illustration and placed alone on a page. For the narrative versions, the small amount of text that was in the original versions of each book was removed and replaced with a single label per page identifying the new target animal (e.g., lion, fox). In didactic books, it is common for objects or characters to appear singly on a page and once in the book. Thus for the didactic versions, the animals were cropped as closely as possible from the original scene and placed in the centre of a blank page with a single label per page identifying the new target animal. The final page in every book displayed all the animals together either as in the original illustration or cropped and placed in a line across the page. 
Table I. Description of page content by version for "Animals in the Woods"

\begin{tabular}{|c|c|c|c|}
\hline \multirow[t]{2}{*}{ Page Number } & \multirow[t]{2}{*}{ Text } & \multicolumn{2}{|c|}{ Page Description by Version } \\
\hline & & Didactic & Narrative \\
\hline $\mathrm{I}$ & Bear & bear in centre of page & $\begin{array}{l}\text { The bear is hibernating on } \\
\text { a bed of snow and leaves. }\end{array}$ \\
\hline 2 & Hare & hare in centre of page & $\begin{array}{l}\text { The hare is hopping } \\
\text { through the woods and is } \\
\text { looking at the bear } \\
\text { sleeping in its cave. }\end{array}$ \\
\hline 3 & Badger & badger in centre of page & $\begin{array}{l}\text { The hare is cuddled up on } \\
\text { top of the bear. A badger } \\
\text { is standing in the snow } \\
\text { about to climb on top of } \\
\text { the bear. }\end{array}$ \\
\hline 4 & Fox & fox in centre of page & $\begin{array}{l}\text { A fox, standing in deep } \\
\text { snow, is looking at the } \\
\text { three animals cuddled up } \\
\text { together in the cave in the } \\
\text { distance. The hare's and } \\
\text { badger's set of paw prints } \\
\text { can be seen in the snow } \\
\text { leading up to the cave. }\end{array}$ \\
\hline 5 & Squirrel & squirrel in centre of page & $\begin{array}{l}\text { A squirrel, sitting in a tree, } \\
\text { is looking at the four } \\
\text { animals cuddled up } \\
\text { together in the cave down } \\
\text { below. Three sets of prints } \\
\text { can now be seen leading } \\
\text { into the cave. }\end{array}$ \\
\hline 6 & Mouse & mouse in centre of page & $\begin{array}{l}\text { A mouse, standing at the } \\
\text { entrance to the cave, is } \\
\text { looking at the five animals } \\
\text { cuddled up together and is } \\
\text { about to join them. }\end{array}$ \\
\hline 7 & -- & $\begin{array}{l}\text { All six animals are walking } \\
\text { in a line on a solid white } \\
\text { background. }\end{array}$ & $\begin{array}{l}\text { All six animals are cuddled } \\
\text { up together. The mouse is } \\
\text { sleeping in the bear's ear. }\end{array}$ \\
\hline
\end{tabular}

Dyads shared either the narrative Zoo book and didactic Woods book or the narrative Woods book and didactic Zoo book, which allowed for a within-subject comparison. Order was fully counterbalanced. 


\section{Procedure}

Mothers and children sat together in a large chair or beside each other in separate chairs, as preferred. All interactions were videotaped. The first book to be shared was placed on top of a box beside the chair, and mothers were instructed to retrieve the second book from inside the box when finished with the first and to put the first book away. Mothers were asked to share the book as they would at home and to go through each book only once from cover to cover. Following book sharing, mothers completed a questionnaire about home book sharing practices.

\section{Transcription}

All interactions were transcribed using the CHAT (Codes for the Human Analysis of Transcriptions) transcription system (MacWhinney \& Snow, 1990; MacWhinney, 2000). Mothers' mean length of utterance in morphemes was computed using CLAN (MacWhinney, 2000).

\section{Coding}

Only mothers' book content-related utterances were coded. Feedback utterances (e.g., "that's right"), book convention utterances (e.g., "turn the page"), and utterances outside of the book reading interaction (e.g., "yes, this chair is purple”) were not.

All utterances were first coded with respect to function. Where relevant (as described further below), utterances were coded according to verb tense and the inclusion of mental state references. A description of each of the coding variables follows. Table 2 presents our coding variables, their subtypes, and examples from the transcripts.

Function. Each utterance was coded as fulfilling one of 16 discrete function types (see Table 2 for a listing), that were divided into two levels: simple and complex. Among these functions, event description utterances were considered simple if they contained an intransitive verb (e.g., "the bear is sleeping) and complex if the verb was transitive (e.g., "the gorilla is unlocking the cage"). Under the fact/background information subtype (complex), we placed only facts about animals that were not directly observable on the page (e.g.,"he (armadillo) has a hard shell, like armour"). In contrast, "the giraffe has a long neck" was coded as a feature description (simple). 
Table 2. Function, tense, and mental state content coding scheme with mean number of utterances for subtypes observed by book genre.

\begin{tabular}{|c|c|c|c|c|}
\hline $\begin{array}{l}\text { Utterance coding } \\
\text { variable }\end{array}$ & \multirow[t]{2}{*}{ Subtype } & \multirow[t]{2}{*}{ Examples } & \multirow[t]{2}{*}{$\begin{array}{l}\text { Narrative } M \\
(S D)\end{array}$} & \multirow[t]{2}{*}{$\begin{array}{l}\text { Didactic M } \\
(S D)\end{array}$} \\
\hline I. Function & & & & \\
\hline a) Simple & Request for label & $\begin{array}{l}\text { "what's this guy } \\
\text { called?" }\end{array}$ & $6.08(4.95)$ & $6.12(5.64)$ \\
\hline & $\begin{array}{l}\text { Request for } \\
\text { description }\end{array}$ & $\begin{array}{l}\text { "what's the } \\
\text { giraffe doing?" }\end{array}$ & $2.12(2.30)$ & $0.52(0.82)$ \\
\hline & $\begin{array}{l}\text { Request for child to } \\
\text { point }\end{array}$ & $\begin{array}{l}\text { "where's the } \\
\text { bear?" }\end{array}$ & $3.24(4.67)$ & $3.28(4.42)$ \\
\hline & $\begin{array}{l}\text { Request for animal } \\
\text { sound }\end{array}$ & $\begin{array}{l}\text { "what does an } \\
\text { elephant say?" }\end{array}$ & $1.32(1.68)$ & $1.16(1.28)$ \\
\hline & $\begin{array}{l}\text { Request for } \\
\text { confirmation }\end{array}$ & $\begin{array}{l}\text { "is that a } \\
\text { giraffe?" }\end{array}$ & $2.84(2.46)$ & $1.56(2.57)$ \\
\hline & Correction & $\begin{array}{l}\text { "that's not a } \\
\text { kitty" }\end{array}$ & $0.32(0.85)$ & $0.40(0.87)$ \\
\hline & Label & $\begin{array}{l}\text { "that's called } \\
\text { an armadillo" }\end{array}$ & $14.00(11.14)$ & $12.72(3.74)$ \\
\hline & Feature description & $\begin{array}{l}\text { "he has a long } \\
\text { trunk" }\end{array}$ & $\mathrm{I} .76(2.3 \mathrm{I})$ & $2.24(2.47)$ \\
\hline & $\begin{array}{l}\text { Intransitive event } \\
\text { description }\end{array}$ & $\begin{array}{l}\text { "the animals } \\
\text { are all running" }\end{array}$ & $3.60(2.94)$ & $0.64(1.18)$ \\
\hline \multirow[t]{7}{*}{ b) Complex } & $\begin{array}{l}\text { Request for } \\
\text { judgement }\end{array}$ & $\begin{array}{l}\text { "where do you } \\
\text { think the } \\
\text { squirrel is going } \\
\text { to go?" }\end{array}$ & $2.08(2.4 I)$ & $\mathrm{I} .48(\mathrm{I} .48)$ \\
\hline & $\begin{array}{l}\text { Fact/Background } \\
\text { information }\end{array}$ & $\begin{array}{l}\text { "badgers use } \\
\text { their sharp } \\
\text { claws and go } \\
\text { dig, dig, dig" }\end{array}$ & $0.64(0.70)$ & $0.64(0.95)$ \\
\hline & $\begin{array}{l}\text { Text-to-life } \\
\text { reference }\end{array}$ & $\begin{array}{l}\text { "we saw a } \\
\text { squirrel this } \\
\text { morning in the } \\
\text { backyard" }\end{array}$ & I.56 (2.00) & $.68(0.95)$ \\
\hline & Comparison & $\begin{array}{l}\text { "he kind of } \\
\text { looks like a } \\
\text { bug" }\end{array}$ & $0.96(1.24)$ & $0.68(1.18)$ \\
\hline & Prediction & $\begin{array}{l}\text { "he'll be } \\
\text { surprised in the } \\
\text { morning, huh?" }\end{array}$ & $0.36(0.64)$ & $0(0)$ \\
\hline & Judgement/Inference & $\begin{array}{l}\text { "he's been } \\
\text { fed...there's } \\
\text { peanuts all over } \\
\text { the floor" }\end{array}$ & $1.04(1.34)$ & $0.12(0.44)$ \\
\hline & $\begin{array}{l}\text { Transitive event } \\
\text { description }\end{array}$ & $\begin{array}{l}\text { "the hare sees } \\
\text { a badger" }\end{array}$ & $4.12(3.54)$ & $1.12(1.27)$ \\
\hline
\end{tabular}




\begin{tabular}{|c|c|c|c|c|}
\hline $\begin{array}{l}\text { Utterance coding } \\
\text { variable }\end{array}$ & Subtype & Examples & $\begin{array}{l}\text { Narrative } M \\
\text { (SD) }\end{array}$ & $\begin{array}{l}\text { Didactic M } \\
\text { (SD) }\end{array}$ \\
\hline \multirow[t]{4}{*}{$\begin{array}{l}\text { 2. Tense (if } \\
\text { applicable) }\end{array}$} & Past & $\begin{array}{l}\text { "the squirrel } \\
\text { went in there" }\end{array}$ & $1.92(2.36)$ & $0.44(0.92)$ \\
\hline & Present & $\begin{array}{l}\text { "the bear is } \\
\text { sleeping" }\end{array}$ & $8.04(5.11)$ & $\mathrm{I} .84(2.36)$ \\
\hline & Future & $\begin{array}{l}\text { "do you think } \\
\text { the squirrel's } \\
\text { going to go see } \\
\text { his friends?" }\end{array}$ & $1.56(1.89)$ & $0.12(0.33)$ \\
\hline & Timeless & $\begin{array}{l}\text { "the fox runs } \\
\text { really fast" }\end{array}$ & $2.48(2.40)$ & $4.20(4.24)$ \\
\hline \multirow[t]{3}{*}{$\begin{array}{ll}\text { 3. } & \text { Mental state } \\
\text { references (if } \\
\text { applicable) }\end{array}$} & Child's mental state & $\begin{array}{l}\text { "do you } \\
\text { remember what } \\
\text { Daddy said } \\
\text { squirrels do?" }\end{array}$ & $3.60(4.03)$ & $2.24(2.74)$ \\
\hline & $\begin{array}{l}\text { Mother's mental } \\
\text { state }\end{array}$ & $\begin{array}{l}\text { "I don't think } \\
\text { we saw that } \\
\text { one at the zoo" }\end{array}$ & $.88(1.30)$ & $.44(.82)$ \\
\hline & $\begin{array}{l}\text { Character's mental } \\
\text { state }\end{array}$ & $\begin{array}{l}\text { "does he want } \\
\text { to cuddle too?" }\end{array}$ & $1.24(2.02)$ & $.20(1.00)$ \\
\hline
\end{tabular}

Tense. We coded all utterances for tense except those in three function subtypes (request for a label, request for pointing, labelling) which did not logically permit tense variation (e.g., "that's a hyena"). Among all remaining utterances, the main verb was coded as past, present, future or timeless. Utterances were coded as past if the verb was in the past tense (e.g., "we saw lions at the zoo") and as present if the verb was in the present progressive (e.g., "the gorilla is stealing the keys!"). Utterances that referred to the future in terms of probability or intent were coded as future (e.g., "I bet he's going to go in there too"). Ongoing or permanent actions or states (e.g., "he likes to say roar"), framed in the present simple, were coded as timeless.

Mental State References. All content-related utterances were inspected for mental state references. Mental state references were categorized into those that referred to the child's (e.g., "where do you think he's going?"), mother's (e.g., "I wonder what the lion is doing”), or a character's mental state (e.g., "he wants to cuddle with his friends"). We included all instances of verbs referring to cognitive states (e.g., remember), desire states (e.g., want), and perception states (e.g., see). 
Coding Reliability. A second coder, blind to the purposes of the study, coded a randomlyselected $32 \%$ of the transcripts for each genre. Reliability was excellent, with agreement for each category as follows: function (91\%), tense (94\%), and mental state reference (100\%).

\section{Results}

We conducted a series of preliminary independent-sample $t$-tests to examine differences between boys and girls, book pairing (i.e., didactic woods and narrative zoo versus didactic zoo and narrative woods), and presentation order (didactic-narrative versus narrativedidactic). No significant effects were found. Therefore, we present data for all groups together in the following sections. Where multiple post hoc $t$-tests were conducted, we applied Bonferroni corrections. In the case of violations of the assumption of sphericity, we made Greenhouse-Geisser adjustments to the degrees of freedom. Throughout, we report Pearson's $r$ correlations as an index of individual differences, with significant correlations indicating that mothers' talk across the two book genres demonstrated consistency.

\section{Number and length of utterances}

Dyads spent significantly longer on narrative book sharing ( $M=186.44 \mathrm{~s}, S D=118.09 \mathrm{~s}$, range $=68$ to $541 \mathrm{~s})$ than didactic book sharing $(M=144.44 \mathrm{~s}, S D=72.05 \mathrm{~s}$, range $=51$ to 311 s), $t(24)=2.49, p=.02, d=.43$. At the individual level, 18 of the 25 dyads fit this trend. The duration of the interaction was significantly correlated across genres $r(25)=.41, p<.001)$.

Consistent with the duration data, the number of utterances mothers produced was significantly greater in narrative book sharing $(M=47.20, S D=26.17)$ than in didactic book sharing $(M=33.80, S D=14.18), t(24)=2.97, p=.007, d=.64$. Seventeen of the 25 mothers showed this pattern. Additionally, mothers' mean length of utterance (MLU) during narrative book sharing was significantly longer $(M=4.06, S D=.84)$ than during didactic book sharing $(M=3.59, S D=.82), t(24)=3.54, p=.002, d=.56$. This pattern was observed among 20 of the 25 mothers. Strong correlations were found between the two genres for mothers' total number of utterances $(r(25)=.51, p=.009)$ and $\mathrm{MLU}(r(25)=.69, p<.001)$. Because mothers talked more during narrative book sharing, we calculated both the number of utterances (frequency) and proportion of total utterances for each category to provide an accurate comparison of the two book types. Unless otherwise indicated, proportions were calculated by dividing the number of utterances for a particular variable by the total number of maternal utterances per genre. For reasons of space, we report the frequency results for each category and only report the proportion results when they differed from the frequency results. 


\section{Complexity of Talk}

A 2 x 2 repeated-measures ANOVA with genre (narrative and didactic) and complexity (simple and complex) as within-subject factors was conducted. Mothers produced significantly more simple and complex utterances when sharing narrative books $(M=23.60$, $S D=13.08)$ than didactic books $(M=16.90, S D=7.09), F(1,24)=8.90, p=.006, \eta^{2} \mathrm{p}=.27$. See Table 2 for means for the individual function categories. Mothers also produced significantly more simple utterances $(M=32.18, S D=15.25)$ than complex utterances $(M=8.32, S D=$ 4.54) across both genres, $F(1,24)=75.09, p<.001, \eta^{2} \mathrm{p}=.76$. The genre $\mathrm{x}$ complexity interaction was not significant, $p=.831, \eta^{2} \mathrm{p}=.002$. All 25 mothers produced more simple utterances than complex utterances. Proportional analyses revealed, however, that, consistent with our predictions, a significantly greater proportion of utterances was complex during narrative book sharing $(M=25 \%)$ than during didactic book sharing $(M=15 \%), t(24)$ $=4.58, p<.001, d=1.01$. Twenty-one of the 25 mothers had a larger proportion of complex utterances during narrative book sharing than didactic book sharing. Across genres, both mothers' frequency $(r(25)=.45, p=.025)$ and proportion of complex utterances $(r(25)=.40, p$ $=.05)$ were significantly correlated.

\section{Tense}

To compare mothers' framing of utterances in the various tenses, we conducted a $2 \times 4$ repeated-measures ANOVA with genre (narrative or didactic) and tense (past, present, future, or timeless) as within-subjects variables. Mothers produced significantly more tensecoded utterances during narrative book sharing $(M=3.50, S D=2.08)$ than during didactic book sharing $(M=1.65, S D=1.39), F(1,24)=17.38, p<.001, \eta^{2} \mathrm{p}=.42$. There was a significant main effect of tense, $F(2.32,55.78)=22.88, p<.001, \eta^{2} \mathrm{p}=.49$, and a significant genre $\mathrm{x}$ tense interaction, $F(3,72)=24.57, p<.001, \eta^{2} \mathrm{p}=.51$. Looking at the interaction, we found that mothers produced significantly more past $(t(24)=2.98, p=.007, d=.83)$, present $(t(24)=6.28, p<.001, d=1.56)$, and future tense $(t(24)=3.80, p=.001, d=1.06)$ utterances during narrative book sharing (see Table 2 for means). Slightly more utterances were framed in a timeless tense during didactic book sharing $(t(24)=2.03, p=.054, d=.50)$. Neither mothers' overall frequency of tense-coded utterances nor their frequency of any individual tense was correlated across genres ( $p=.14$ to .792). The results for proportion mirror those for frequency in terms of statistical significance.

With respect to individual results, fourteen mothers framed more utterances in the past during narrative book sharing than didactic book sharing. Seven mothers never framed 
utterances in the past tense. Fifteen mothers framed more utterances in the future tense during narrative book sharing, while nine did not produce any utterances in the future tense.

Tense Variety. Mothers' tense variety - the number of different tenses produced when sharing the two types of books out of the possible four tenses coded-was significantly greater during narrative book sharing $(M=2.92$ out of $4, S D=.91)$ than during didactic book sharing $(M=1.76$ out of $4, S D=.93), t(24)=5.07, p<.001, d=1.77$. Eighteen mothers displayed greater tense variety during narrative book sharing, with five showing an equal amount across the two genres. Mothers' tense variety was not significantly correlated across genres, $r(25)=.22, p=.282$.

\section{Mental State References}

A $2 \times 3$ repeated-measures ANOVA with genre (narrative or didactic) and referent (child, mother, or character) as within-subjects factors revealed that mothers' utterances contained significantly more mental state references during narrative book sharing $(M=1.91$ per referent, $S D=1.77)$ than didactic book sharing $(M=.96$ per referent, $S D=1.07), F(1,24)=$ $15.95, p=.001, \eta^{2} \mathrm{p}=.40$. The main effect of referent was significant, $F(1.27,30.36)=11.00, p$ $=.001, \eta^{2} \mathrm{p}=.31$. The genre $\mathrm{x}$ referent interaction was not significant, $p=.21, \eta^{2} \mathrm{p}=.06$. To look at the main effect of referent, we compared references to the child's $(M=2.92, S D=$ $3.20)$, mother's $(M=.66, S D=.89)$, and characters' mental state $(M=.72, S D=1.37)$. Mothers made significantly more references to the child's mental state than to their own, $t(24)=3.93$, $p=.001, d=.96$, or the characters', $t(24)=3.16, p=.004, d=.89$. Twenty mothers made more references to mental states overall during their narrative book sharing than during didactic book sharing. One mother made an equal number of references across the two genres. Mothers' overall frequency of mental state references $(r(25)=.76, p<.001)$ was significantly correlated across genres. The results for proportion mirror those for frequency in terms of statistical significance.

Mental state terms. To provide a more qualitative picture of mothers' mental state talk, we did a simple frequency count of mental state terms across all mothers for each genre. During narrative book sharing, see was the most common term (35 instances), followed by think (32), know (18), remember (14), want (10), wonder(4), and bet(3). Sure (i.e., "are you sure?"), pretend, hope, learn, and guess were all used once. During didactic book sharing, know was the most frequently used term (20), followed by see (19), think (17), and remember (8). Bet, and sure were each used once. 


\section{Discussion}

Using a within-subjects design and carefully controlling for potentially confounding factors including book length, amount of text, and target content, we investigated the effect of picture book genre - narrative versus didactic - on maternal talk.

Consistent with our predictions, a significantly greater proportion of mothers' utterances was complex during narrative book sharing. The ratio of complex to simple talk we observed in narrative book sharing, $25 \%$ to $75 \%$, was similar to the levels found in other studies (van Kleeck et al., 1997), a ratio which van Kleeck (2003) has argued may reflect a scaffolding process.

Analyzed by frequency or proportion, mothers produced significantly more present (progressive), past, and future tense utterances, as well as significantly greater tense variety during narrative book sharing. More complex talk emerged from mothers' past- and futureframed utterances during narrative book sharing. Uses of the past tense commonly included references to something that happened earlier in the book (e.g., "the elephant came out too and there he is now") or in the child's life (e.g., "remember when we saw an elephant on TV?"). Mothers used the future tense most often to make predictions about upcoming events in the story (e.g., "he's going to be surprised in the morning, huh?") or ask the child to make a prediction (e.g., "where do you think the squirrel is going to go now?").

Significantly more timeless utterances were produced during didactic book sharing. Indeed, the timeless tense was used more than the other three tenses combined during didactic book sharing (e.g., comments about the attributes of the animals or the sounds they make). Only two mothers produced future tense utterances during didactic book sharing by asking which animal was going to appear on the next page.

Mothers produced significantly more mental state references when sharing narrative books than didactic ones and most often referenced the child's mental state with respect to an opinion (e.g., "do you think the man sees all the animals?") or prediction (e.g., "what do you think the bear is going to do?"). Mothers' frequent reference to the child's mental states is consistent with findings of Taumoepeau and Ruffman (2008) who studied mothers' mental state talk with children 15- to 33-months-old.

Across mothers, we observed differences in individual communicative style that were consistent across the two book genres. Specifically, mothers' duration of talk, number of utterances, MLU, complexity of talk and their mental state talk were significantly correlated within each variable across the two genres, but their use of tenses was not. Despite this, our within-subjects design revealed that mothers' talk was also significantly influenced by book 
genre. For example, regardless of whether mothers were generally low, medium, or high in their use of complex talk, they, on average, included more complex talk during narrative book sharing. These findings serve to underscore the need to carefully consider potential situational factors when examining communicative interactions, rather than simply attributing features of an interactant's talk to an enduring individual style.

Our findings differ from the findings from previous studies reviewed in our introduction comparing the effect of book genre on mothers' language use. These studies found more complex talk during non-narrative book sharing (Anderson et al., 2004; Price et al., 2009; Torr \& Clugston, 1999). However, for the reasons we outlined in our introduction, we predicted a different, and potentially opposite, pattern for toddler-aged children, given both their younger age and the types of books they typically encounter.

\section{The importance of early narratives}

Mothers' language during narrative book sharing appeared to be encouraging the same types of thought processes in which we, as adult consumers of fiction, commonly engage, such as anticipating outcomes, picking up on uses of foreshadowing, and detecting patterns or similarities (e.g., Oatley, 1999). One outstanding issue for further study that we recognize at this point is that, given the design of the books in our study, we cannot pinpoint the exact features of the narrative book that engendered the more complex types of talk we observed among mothers. As a first study, and for reasons of ecological validity, the two versions of our books were designed to capture the key difference between commercially available narrative and didactic board books - namely isolated images versus a full illustrated story with little text. Thus, our narrative books differed from our didactic books both with respect to containing illustrations with details beyond the storyline (e.g., background features such as the house of the zookeeper) and a continuous storyline, which, given the simple nature of these books, we would describe as a set of contingent serial events happening over a space of time. It is not possible to determine if one or both of these differences led to mothers' more complex talk. But more important, as we mentioned earlier, is that previous studies comparing different genres of books for children have suggested that the talk afforded by narrative books is less complex than that of didactic books. Our results suggest that this should not always be assumed to be the case.

Although we predicted that our narrative books would encourage more complex talk than our didactic books, we were intrigued to find how these simple, very short storybooks encouraged narrations by mothers with young pre-readers that included some of the same characteristics as mature narratives (i.e., event descriptions, mental state references, and 
tense shifting). Event descriptions and mental state references can be viewed as early forms of core aspects of narrative proposed by influential narrative researchers and theorists, such as the landscapes of action and consciousness of Bruner (1986).

Another essential characteristic of narratives is that they take place in time and may be told in a number of different ways by shifting temporal focus (the point in time in a story to which we direct our attention) or temporal viewpoint (the place in time from which we view the story) (Turner, 1996). Tense shifting achieves this, and mothers in our study shifted temporal focus by highlighting events that had happened or were likely about to happen (e.g., "the giraffe came out of his cage"). Thus, our results suggest that even narratives designed for toddlers encourage the use of rudimentary forms of this temporal component of narrative.

Exposure to rich narratives at an early age may be important for a range of different abilities, such as children's later ability to build rich accounts of past events and their information recall (e.g., Lange \& Carroll, 2003; Reese, Haden, \& Fivush, 1993), social functioning (Mar, Tackett, and Moore, 2010), and broader linguistic and cognitive abilities (e.g., van Kleeck et al., 1997; Whitehurst et al., 1988). A large body of research also shows that frequent book sharing in general is correlated with language gains for the child (Arterberry, Midgett, Putnick, \& Bornstein, 2007; Bus, van IJzendoorn, \& Pellegrini, 1995; Farrant, \& Zubrick, in press). Our finding that simple, seven-page, essentially wordless picture storybooks brought about the use of key elements of narrative suggests the possibility that regular exposure to these types of books may lay the foundation for children's later narrative abilities. Further study will be needed to assess the impact that early exposure to complex language during storybook sharing, of the kind we observed in our study, might have on children. For example, whereas narrative book sharing may contribute to abstract thinking skills and perspective-taking abilities, didactic book sharing may be a better arena for word and fact learning, although picture books in general also have been shown to be an excellent source of new and unusual vocabulary for children (e.g., Ard \& Beverly, 2004; De Temple \& Snow, 2003; Walsh \& Blewitt, 2006, but see Evans, Reynolds, Shaw, \& Pursoo, 2011).

\section{Conclusion}

Our findings demonstrate that narrative wordless picture books for toddlers provide greater stimulus for complex maternal talk than their didactic counterparts. This variation in maternal style as a function of book genre highlights the importance of variety in book selection. In both the mainstream media (e.g., Bosman, 2010) and research studies (e.g., Torr \& Clugston, 1999) the value of picture books has been questioned. We would argue that 
parents should not forgo opportunities to share picture storybooks, regarded perhaps as more play-oriented especially when wordless, in favour of more "educational" books, as such books appear to afford unique opportunities for more complex talk.

\section{Acknowledgments}

We thank Olivia Daub for assistance with coding and the parents and children of the Kitchener-Waterloo community for making this research possible.

\section{Funding}

This research was supported by a Research Development Initiative grant awarded to author DKO from the Social Sciences and Humanities Research Council of Canada.

\section{References}

Adrian, J.E., Clemente, R.A., \& Villanueva, L. (2007). Mothers' use of cognitive state verbs in picture-book reading and the development of children's understanding of mind: A longitudinal study. Child Development, 78(4), 1052-1067.

Alborough, J. (2001). Hug. Cambridge, MA: Candlewick Press.

Anderson, J., Anderson, A., Lynch, J., \& Shapiro, J. (2004). Examining the effects of gender and genre on interactions in shared book reading. Reading Research and Instruction, 43(4), 1-20.

Ard, L.M., \& Beverly, B.L. (2004). Preschool word learning during joint book reading: Effect of adult questions and comments. Communication Disorders Quarterly, 26(1), 17-28.

Arterberry, M.E., Midgett, C., Putnick, D.L., \& Bornstein, M.H. Early attention and literacy experiences predict adaptive communication. First Language, 27(2), 175-189.

Beals, D.E., \& Snow, C.E. (1994). "Thunder is when the angels are upstairs bowling": Narratives and explanations at the dinner table. Journal of Narrative \& Life History, 4(4), 331-352.

Beals, D.E., \& Tabors, P.O. (1995). Arboretum, bureaucratic, and carbohydrates:

Preschoolers' exposure to rare vocabulary at home. First Language, 15(1), 57-76.

Bosman, J. (2010, October 7). Picture books no longer a staple for children. New York Times. Retrieved from: http://www.nytimes.com/2010/10/08/us/08picture.html.

Bruner, J. (1986). Actual minds, possible worlds. Cambridge, MA, US: Harvard University Press. 
Bus, A.G., van IJzendoorn, M.H., \& Pellegrini, A.D. (1995). Joint book reading makes for success in learning to read: A meta-analysis on intergenerational transmission of literacy. Review of Educational Research, 65(1), 1-21.

Cansler, D.C., \& Stiles, W.B. (1981). Relative status and interpersonal presumptuousness. Journal of Experimental Social Psychology, 17(5), 459-471.

De Temple, J., \& Snow, C.E. (2003). Learning words from books. In A. van Kleeck, S.A. Stahl \& E.B. Bauer (Eds.), On reading books to children: Parents and teachers. (pp. 16-36). Mahwah, NJ, US: Lawrence Erlbaum Associates Publishers.

Dewaele, J., Eckert, P., \& Rickford, J.R. (2001). Style and sociolinguistic variation. Journal of Language and Social Psychology, 22(2), 234-238.

Dickinson, D.K., De Temple, J.M., Hirschler, J.A., \& Smith, M.W. (1992). Book reading with preschoolers: Coconstruction of text at home and at school. Early Childhood Research Quarterly, 7(3), 323-346.

Evans, M.A., Reynolds, K., Shaw, D., Pursoo, T. (2011). Parental explanations of vocabulary during shared book reading: A missed opportunity. First Language, 31(2), 195-213.

Farrant, B., \& Zubrick, S. (in press). Early vocabulary development: The importance of joint attention and parent-child book reading. First Language, DOI: $10.1177 / 0142723711422626$.

Haden, C.A., Reese, E., \& Fivush, R. (1996). Mothers' extratextual comments during storybook reading: Stylistic differences over time and across texts. Discourse Processes, 21(2), 135-169.

Harkins, D.A., Koch, P.E., \& Michel, G.F. (1994). Listening to maternal story telling affects narrative skill of 5-year-old children. The Journal of Genetic Psychology, 155(2), 247257.

Heath, S. B. (1982). What no bedtime story means: Narrative skills at home and school. Language in Society, 11(1), 49-76.

Hoff, E. (2010). Context effects on young children's language use: The influence of conversational setting and partner. First Language, 30(3-4), 461-472.

Hoicka, E., Jutsum, S., \& Gattis, M. (2008). Humor, abstraction, and disbelief. Cognitive Science, 32(6), 985-1002.

Kang, J.Y., Kim, Y.-S., Pan, B.A. (2009). Five-year-olds' book talk and story retelling: Contributions of mother-child bookreading. First Language, 29(3), 243-265.

Korat, O., \& Or, T. (2010). How new technology shapes the parent-child interaction. First Language, 30(2), 139-154. 
Lange, G., \& Carroll, D.E. (2003). Mother-child conversation styles and children's laboratory memory for narrative and nonnarrative materials. Journal of Cognition and Development, 4(4), 435-457.

Lewis, C., \& Gregory, S. (1987). Parents' talk to their infants: The importance of context. First Language, 7(21), 201-216.

MacWhinney, B. (2000). The CHILDES project: Tools for analyzing talk (3rd Edition.) Mahwah, NJ: Lawrence Erlbaum Associates.

MacWhinney, B., \& Snow, C. (1990). The child language data exchange system: An update. Journal of Child Language, 17(2), 457-472.

Mar, R.A., Tackett, J.L., \& Moore, C. (2010). Exposure to media and theory-of-mind development in preschoolers. Cognitive Development, 25(1), 69-78.

Moerk, E.L. (1985). Picture book reading by mothers and young children and its impact upon language development. Journal of Pragmatics, 9, 547-566.

Moore, C., Furrow, D., Chiasson, L., \& Patriquin, M. (1994). Developmental relationships between production and comprehension of mental terms. First Language, 14(42-43), 117.

Morgan, L., \& Goldstein, H. (2004). Teaching mothers of low socioeconomic status to use decontextualized language during storybook reading. Journal of Early Intervention, 26(4), 235-252.

Murray, M.D. (2003). Don't Wake Up the Bear! Tarrytown, NY: Marshall Cavendish Corporation.

Oatley, K. (1999). Meeting of minds: Dialogue, sympathy, and identification in reading fiction. Poetics, 26, 439-454.

O'Neill, D.K., \& Atance, C.M. (2000). 'Maybe my daddy give me a big piano': The development of children's use of modals to express uncertainty. First Language, 2O(1), 29-52.

Pawlak, A., Oehlrich, J., \& Weist, R. (2006). Reference time in child English and Polish. First Language, 26(3), 259-280.

Pellegrini, A.D., Brody, G.H., \& Sigel, I.E. (1985). Parents' teaching strategies with their children: The effects of parental and child status variables. Journal of Psycholinguistic Research, 14(6), 509-521.

Price, L.H., van Kleeck, A., \& Huberty, C.J. (2009). Talk during book sharing between parents and preschool children: A comparison between storybook and expository book conditions. Reading Research Quarterly, 44(2), 171-194.

Rathmann, P. (1994). Good Night, Gorilla. New York, NY: G.P. Putnam's Sons. 
Reese, E., \& Cox, A. (1999). Quality of adult book reading affects children's emergent literacy. Developmental Psychology, 35(1), 20-28.

Reese, E., Cox, A., Harte, D., \& McAnally, H. (2003). Diversity in adults' styles of reading books to children. In A. van Kleeck, S.A. Stahl \& E.B. Bauer (Eds.), On reading books to children: Parents and teachers. (pp. 37-57). Mahwah, NJ, US: Lawrence Erlbaum Associates Publishers.

Reese, E., Haden, C.A., \& Fivush, R. (1993). Mother-child conversations about the past: Relationships of style and memory over time. Cognitive Development, 8(4), 403-430.

Ross, L.D., Amabile, T.M., \& Steinmetz, J.L. (1977). Social roles, social control, and biases in social-perception processes. Journal of Personality and Social Psychology, 35(7), 485-494.

Sénéchal, M., Cornell, E.H., \& Broda, L.S. (1995). Age-related differences in the organization of parent-infant interactions during picture-book reading. Early Childhood Research Quarterly, 10(3), 317-337.

Sorsby, A.J., \& Martlew, M. (1991). Representational demands in mothers' talk to preschool children in two contexts: Picture book reading and a modelling task. Journal of Child Language, 18(2), 373-395.

Taumoepeau, M., \& Ruffman, T. (2008). Stepping stones to others' minds: Maternal talk relates to child mental state language and emotion understanding at 15,24 , and 33 months. Child Development, 79(2), 284-302.

Torr, J., \& Clugston, L. (1999). A comparison between informational and narrative picture books as a context for reasoning between caregivers and 4-year-old children. Early Child Development and Care, 159, 25-41.

Trudeau, N., \& Sutton, A. (2011). Expressive vocabulary and early grammar of 16- to 30month-old children acquiring Quebec French. First Language, 31(4), 480-507.

Turner, M. (1996). The Literary Mind. Oxford University Press: New York, NY.

van Kleeck, A. (2003). Research on book sharing: Another critical look. In A. van Kleeck, S.A. Stahl \& E.B. Bauer (Eds.), On reading books to children: Parents and teachers. (pp. 271-320). Mahwah, NJ, US: Lawrence Erlbaum Associates Publishers.

van Kleeck, A., Gillam, R.B., Hamilton, L., \& McGrath, C. (1997). The relationship between middle-class parents' book-sharing discussion and their preschoolers' abstract language development. Journal of Speech \& Hearing Research, 40(6), 1261-1271.

Walsh, B. A., \& Blewitt, P. (2006). The effect of questioning style during storybook reading on novel vocabulary acquisition of preschoolers. Early Childhood Education Journal, 33(4), 273-278. 
Whitehurst, G.J., Falco, F.L., Lonigan, C.J., Fischel, J.E., DeBaryshe, B.D., Valdez-Menchaca, M.C., et al. (1988). Accelerating language development through picture book reading. Developmental Psychology, 24(4), 552-559.

Zevenbergen, A.A., \& Whitehurst, G.J. (2003). Dialogic reading: A shared picture book reading intervention for preschoolers. In A. van Kleeck, S.A. Stahl \& E.B. Bauer (Eds.), On reading books to children: Parents and teachers. (pp. 177-200). Mahwah, NJ, US: Lawrence Erlbaum Associates Publishers. 